\title{
KEMAMPUAN NUMBER SENSE MELALUI METODE LEARNING BY PLAYING
}

\author{
Tunjung Susilowati \\ Dosen Pendidikan Guru Sekolah Dasar UNJ \\ tsptsusi@yahoo.com
}

\begin{abstract}
One of many purpose on mathematic teaching is problem solving. Problem solving need good computation abilities. Student have computation abilities if number sense develop in them. Number sense related with flexible and intuitive thinking about number. Number sense is natural ability of human and developed with teaching. This research using learning by playing teaching method to develop number sense. The purpose of choosing this method is student can practice their number sense and observed directly also mathematics can be fun subject. Research conducted with using different kind of games in every session. Based from the research, student developed their number sense on addition and subtraction of integers and they enjoy the learning also.
\end{abstract}

Keywords: Number sense, learning by playing, summation and Equity pbulat numbers.

\begin{abstract}
Abstrak: Salah satu tujuan pembelajaran matematika adalah pemecahan masalah. Pemecahan masalah memerlukan kemampuan berhitung yang baik. Kemampuan berhitung didapat apabila kemampuan number sense berkembang pada diri siswa. Number sense berhubungan dengan pemikiran yang fleksibel dan intuitif tentang bilangan. Number sense merupakan kemampuan alami yang dimiliki oleh semua orang dan dapat berkembang dengan adanya pengajaran. Pengajaran untuk mengembangkan number sense siswa pada penelitian ini dilakukan dengan metode learning by playing. Metode ini dipilih agar kemampuan number sense dapat dipraktikkan dan diamati secara langsung serta pembelajaran matematika menjadi menyenangkan. Penelitian dilakukan dengan mengembangkan permainan yang berbeda pada setiap pertemuan. Berdasarkan penelitian yang dilakukan terlihat adanya peningkatan kemampuan number sense siswa pada penjumlahan dan pengurangan bilangan bulat dan juga siswa menikmati pembelajaran yang dilakukan.
\end{abstract}

Kata kunci: number sense, learning by playing, penjumlahan dan pengurangan bilangan pbulat.

Matematika sebagai salah satu pelajaran yang diberikan di Sekolah Dasar memiliki beberapa tujuan pembelajaran, salah satunya adalah pemecahan masalah. Pemecahan masalah ini akan dikuasai siswa apabila mereka memiliki kemampuan menghitung. Menghitung memerlukan energi yang lebih besar dibandingkan membaca karena pada saat menghitung seseorang pada awalnya harus membaca simbol yang tertulis lantas melakukan kegiatan kedua yaitu melakukan perhitungan itu sendiri. Menghitung akan lebih mudah dilakukan 
Kemampuan Number Sense

Melalui Metode Learning By Playing

Tunjung Susilowati

apabila seseorang telah menghafal faktafakta dasar perhitungan yang terletak pada bilangan 1-10 sehingga menimbulkan otomatisasi dalam benaknya hal ini terjadi di otak seperti seseorang yang hafal abjad a-z lalu diminta untuk membaca maka ia akan secara otomatis tahu apabila diberikan kata 'jari' akan langsung membacanya jari tanpa perlu lagi mengeja satu persatu huruf-hurufnya. Seseorang yang number sensenya berkembang dengan baik akan memiliki otomatisasi ini sehingga pada saat diberikan permasalahan yang perlu dipikirkan adalah operasi bilangan apa yang harus dipilih apakah itu menjumlahkan, mengurangi, mengalikan, atau membagi sedangkan langkah berikutnya yaitu menghitung akan dilakukan secara otomatis tanpa perlu lagi kesulitan untuk memikirkan hubungan antar angka tersebut. Kemampuan number sense penting untuk dikembangkan karena number sense menjadi pembeda antara manusia dengan komputer pada era teknologi canggih ini. (Aliestar,2005: 212)

Definisi mengenai number sense dikemukakan oleh beberapa ahli. Sharon Griffin menyatakan bahwa number sense memerlukan terbentuknya beragam kombinasi hubungan dari ketiga hal yang terdapat pada disiplin ilmu matematika yaitu: kuantitas nyata yang ada di dalam ruang dan waktu, penghitungan angka dalam bahasa lisan, dan simbol formal seperti angka tertulis dan tanda yang digunakan pada operasi Bilangan ( Sharon, 2004: 42).

Rusty (1999) menyatakan number sense sebagai suatu ide besar yang mencakup area pemikiran numerik dimana secara konsep sulit untuk dijelaskan secara tepat namun dapat dikenali apabila siswa menggunakannya. Number sense yang berkembang dapat dikenali pada saat seorang siswa diberikan suatu permasalahan maka dengan lincah ia mencari cara untuk memecahkannya. Bagi Sowder dalam $\operatorname{NCTM}(2000: 32)$ definisi

Number sense yaitu the ability to decompose numbers naturally, use particular numbers like 100 or $1 / 2$ as referents, use the relationships among arithmetic operations to solve problems, understand the base-ten number system, estimate, make sense of numbers, and recognize the relative and absolute magnitude of numbers.

Alistair McIntosh et.al. (2004) menggambarkan number sense refers to a person's general understanding of number and operations along with the ability and inclination to use this 
understanding in flexible ways to make mathematical judgements and to develop useful strategies for handling numbers and operations. Christopher T. Cross et al (2009:95) dalam definisinya mengenai number sense yang dinyatakan sebagai keterkaitan pengetahuan tentang bilangan dan operasinya dimana hal itu terjadi disebabkan adanya kombinasi antara pengetahuan dasar number sense seseorang yang kemudian meningkat karena adanya pengalaman dan pengajaran. Kathy Richardson (2004: 321) memperkuat pendapat ini dengan menyatakan bahwa inti dari Matematika yaitu memiliki sense, dimana hal ini juga harus menjadi inti pengajaran matematika yang kita ajarkan pada anak-anak.

Berdasarkan paparan di atas maka disimpulkan bahwa kemampuan number sense adalah pengertian seseorang tentang bilangan dan operasinya dengan cara yang fleksibel untuk mengembangkan strategi dalam pemecahan masalah dimana hal ini dapat meningkat dengan adanya pengalaman dan pengajaran, dengan demikian kemampuan number sense dapat diajarkan kepada siswa di sekolah. Adapun indikator kemampuan number sense yaitu : (1) mampu menyusun bilangan secara alami, (2) membuat acuan, (3) menggunakan hubungan diantara operasi aritmatika, menerapkan sistem bilangan berbasis sepuluh, (5) melakukan estimasi, dan (6) mengoperasikan besarnya bilangan yang relatif dan mutlak.

Pengajaran yang digunakan untuk meningkatkan kemampuan number sense perlu dipikirkan dengan cermat metode, aktivitas maupun materinya. Metode yang dipilih sebaiknya merupakan metode yang secara aktif melibatkan siswa sekaligus juga memadai bagi pendidik untuk menggali secara langsung dan personal kemampuan siswa agar pendidik dapat mengukur kemampuan number sense masing-masing siswa, selain itu metode yang menyenangkan juga diperlukan karena sebagian besar anak akan senang belajar matematika apabila diajar dengan cara yang menyenangkan sebelum masuk ke dalam simbol abstrak. Metode yang dipakai adalah dengan menggunakan alat peraga seperti misalnya kartu dot (berbentuk seperti domino), kalender, menulis diari, melalui permainan, dan lain-lain. Dehaene menyatakan bahwa otak manusia tidaklah berisi simbol abstrak oleh karena itu dalam mempelajari matematika yang paling penting adalah adanya bentuk nyata. (Stanistas, 
Kemampuan Number Sense

Melalui Metode Learning By Playing

Tunjung Susilowati

2011:126) Siswa akan menggunakan number sense apabila mereka berhadapan langsung dengan situasi numerik atau dengan kata lain kemampuan number sense akan berkembang apabila dipicu oleh adanya konteks yang memerlukan matematika dimana di dalamnya seseorang menciptakan hubungan antar bilangan, hal ini akan membuat anak berpikir tentang angka dengan cara yang fleksibel. Berdasarkan hal ini maka perlu dipikirkan aktivitas yang membuat siswa seringkali berhadapan dengan angka dalam berbagai situasi yang berbeda. Kompetensi matematika berkembang pada anak-anak yang belajar bahwa matematika masuk akal dan percaya bahwa mereka akan dapat memiliki sense tersebut, oleh karena itu materi yang diberikan juga harus membuka wawasan anak sehingga mereka bukan hanya memecahkan masalah dengan cara prosedural saja.

Tujuan diadakannya penelitian ini adalah untuk meningkatkan kemampuan number sense siswa kelas V SD Kristen Calvin dalam penjumlahan dan pengurangan bilangan bulat. Kemampuan number sense yang meningkat diharapkan dapat membuat siswa mencapai tujuan pembelaran yang ditetapkan oleh pemerintah yaitu pemecahan masalah.

\section{METODE}

Metode penelitian yang digunakan dalam penelitian ini adalah penelitian tindakan (action research). Desain intervensi tindakan/rancangan siklus dalam penelitian ini menggunakan model Kemmis dan McTaggart, dengan menggunakan sistem spiral yang dimulai dari perencanaan (planning), tindakan (acting), pengamatan (observing), dan refleksi (replanning) sebagai dasar untuk strategi pemecahan masalah.

Data yang akan dikumpulkan dalam penelitian ini terbagi atas dua macam data yaitu data tes (nilai tes kemampuan number sense siswa) dan data non tes (hasil dari observasi guru dan siswa di kelas), oleh karena itu teknik pengumpulan data dalam penelitian ini pun dibedakan atas dua jenis. Pengumpulan data tes dilakukan dengan menggunakan lembar penilaian kemampuan number sense siswa. Tes dilakukan di setiap akhir siklus atau tindakan ke-2 dari setiap siklus. Soal yang diberikan berupa 10 soal pilihan ganda dan 3 soal uraian. Penilaian terhadap kemampuan number sense didapatkan dari menganalisa jawaban 
yang diberikan siswa. Analisa dilakukan dengan berpedoman pada kisi-kisi instrumen yang telah dibuat. Tes yang dilakukan pada akhir siklus berisikan materi penjumlahan dan pengurangan bilangan bulat. Pengumpulan data non tes dilakukan dengan cara : (1) melalui observasi langsung dengan menggunakan lembar observasi pemantauan proses pembelajaran guru dan siswa. Observasi langsung dilaksanakan sejak awal kegiatan pembelajaran sampai berakhirnya kegiatan pembelajaran, (2) catatan lapangan untuk mencatat setiap tindakan/aktivitas guru maupun siswa, baik yang positif maupun negatif, serta peristiwa apa saja yang memengaruhi pelaksanaan tindakan dalam pembelajaran di kelas, (3) dokumentasi berupa foto-foto selama kegiatan pembelajaran berlangsung, dan (4) wawancara dengan siswa dan observer.

Analisis data pada penelitian ini mencakup analisis data kualitatif dan kuantitatif. Data kualitatif didapatkan dari pengisian lembar pengamatan, catatan lapangan, catatan hasil observasi di lapangan, dan catatan hasil wawancara siswa. Analisis data kualitatif pada penelitian ini dilakukan dengan cara menggabungkan data kualitatif agar dapat diambil kesimpulan sejauh mana metode learning by playing memengaruhi peningkatan kemampuan number sense siswa. Analisis data kuantitatif dilakukan dengan menganalisa data kuantitatif secara deskriptif seperti menghitung jumlah siswa yang tuntas dan belum tuntas, menghitung prosentase nilai, menghitung prosentase skor pengamatan aktivitas guru dan siswa, serta membuat grafik.

\section{HASIL}

Penelitian dilakukan sebanyak 4 siklus dengan 2 kali tindakan setiap siklusnya. Permainan yang digunakan pada siklus I tindakan 1 adalah topi hitam dan merah, sedangkan pada tindakan 2 yaitu permainan maju mundur 1 dan 2 . Permainan zip dan positif atau negatif merupakan permainan yang dilakukan di siklus II. Pelaksanaan tindakan pada siklus II menunjukkan perbedaan yang cukup signifikan dari siklus I yang dapat dilihat dari sedikitnya catatan kekurangan pada lembar pemantauan proses pembelajaran guru dan siswa dan meningkatnya nilai evaluasi pembelajaran. Siklus III memakai permainan menghitung cepat dan domino pengurangan. Siklus IV dirancang dengan memakai permainan tebak angka dan 21. Permainan pada siklus ini cukup efektif yang terlihat dari hampir $89,7 \%$ siswa 
Kemampuan Number Sense

Melalui Metode Learning By Playing

Tunjung Susilowati

mendapatkan nilai di atas KKM. Pelaksanaan tindakan yang terlihat dari lembar pemantauan proses pembelajaran juga telah berjalan dengan baik, oleh karena itu penelitian tidak lagi dilanjutkan pada siklus berikutnya. Hasil evaluasi pembelajaran seperti yang terlihat pada grafik di atas apabila dikelompokkan berdasarkan indikator number sense akan nampak seperti tabel dan grafik.

\section{PEMBAHASAN}

Penelitian ini dianggap berhasil jika telah terjadi peningkatan kemampuan number sense siswa tentang penjumlahan dan pengurangan bilangan bulat melalui penggunaan metode learning by playing. Indikator terjadinya peningkatan kemampuan number sense siswa tentang penjumlahan dan pengurangan bilangan bulat yaitu siswa mampu menyusun bilangan secara alami, siswa mampu membuat acuan/patokan, siswa mampu menerapkan sistem bilangan berbasis sepuluh, siswa mampu melakukan estimasi, siswa mampu mengoperasikan besarnya bilangan yang relatif dan mutlak, serta menggunakan hubungan diantara operasi aritmatika.

Sebelum melaksanakan penelitian, telah dilakukan observasi awal terhadap kemampuan number sense siswa pada pembelajaran matematika. Dari observasi dan dialog didapatkan bahwa siswa masih kurang berkembang kemampuan number sensenya hal ini tercermin dari siswa yang bisa menjawab pertanyaan guru dengan jawaban yang tepat apabila diberi soal berupa angka-angka tetapi pada waktu diberikan variasi soal mereka mengalami kesulitan dalam mengerjakannya dan siswa juga mengalami kesulitan dalam mengkomunikasikan mengapa mereka memilih cara tertentu untuk memecahkan masalah. Hal ini menjadi acuan dalam merancang metode pembelajaran learning by playing. Pada pelaksanaan tindakan siklus I, dilakukan evaluasi hasil belajar pada akhir siklus guna melihat sejauh mana peningkatan kemampuan number sense siswa pada penjumlahan dan pengurangan bilangan bulat. Evaluasi dilakukan dengan memberikan 10 soal pilihan ganda dan 3 soal uraian. Berdasarkan hasil evaluasi didapatkan nilai rata-rata kelas 39 dan hanya ada 5 siswa yang nilainya lebih atau sama dengan KKM yaitu 60. Siswa tampak sangat kesulitan dengan pembacaan soal, karena soal yang diberikan tidak seperti soal yang selama ini diberikan. Misalnya 
seperti soal yang biasa diberikan guru adalah "bilangan berikut ini yang jika dibagi 6 mempunyai sisa 2", sedangkan pada soal yang diujikan dituliskan "bilangan berikut ini yang jika terus ditambah -6 mempunyai sisa 2". Pembacaan soal memerlukan waktu yang lama sehingga waktu 30 menit yang telah direncanakan tidaklah cukup untuk mengerjakan semua soal. Ditambah pula dengan kebiasaan siswa yang lebih senang menuliskan hasil akhir dan kurang mau membiasakan diri untuk menguraikan alasan dari jawaban yang dituliskan, sehingga siswa sangat kesulitan ketika diminta menguraikan jawaban mereka. Meskipun nilai rata-rata kelas rendah, tetapi jika dilihat dari persentase terlihat bahwa ada beberapa aspek yang lebih dari $50 \%$ siswa menguasainya yaitu aspek mempolakan keteraturan bilangan, mengelompokkan bilangan, membuat sistem acuan/patokan, menyimpulkan mengenai adanya hubungan antara konteks masalah dan perhitungan yang sesuai, serta mengemukakan efek dari suatu operasi bilangan. Hal ini menunjukkan bahwa pada dasarnya siswa sudah memiliki beberapa aspek number sense yang berkembang. Perubahan perilaku siswa yang terjadi akibat pembelajaran yang terpantau pada siklus ini yaitu siswa mampu menggambarkan bilangan dengan berbagai cara, hal ini terlihat dari cara siswa mengadaptasi permainan topi merah hitam ke dalam permainan maju mundur 1 dan 2 .

Berdasarkan evaluasi pada siklus I, maka pada saat pelaksanaan siklus II jenis permainan yang dipilih yaitu permainan yang lebih mengembangkan kemampuan siswa dalam hal membuat sistem acuan/patokan, menerapkan sistem bilangan berbasis sepuluh, melakukan estimasi, mengoperasikan besarnya bilanagan yang relatif dan mutlak, serta metode wawancara untuk mendapatkan uraian jawaban yang diiringi dengan guru membimbing siswa untuk menuliskan jawaban pada saat mengerjakan soal. Perpaduan cara ini terbukti efektif karena terjadi peningkatan terhadap hasil evaluasi belajar yaitu nilai rata-rata kelas menjadi 63 dan terdapat 21 siswa yang nilainya $\geq 60$. Pada siklus ini, juga terlihat bahwa ada beberapa siswa yang bisa menemukan metode efisien untuk menghitung utamanya dalam permainan zip. Siswa bisa mengkombinasikan beberapa kartu sekaligus untuk mendapatkan angka yang diperlukan. Beberapa siswa yang menemukan cara ini tercatat sebagai siswa yang sulit untuk 
Kemampuan Number Sense

Melalui Metode Learning By Playing

Tunjung Susilowati

duduk diam dalam mengikuti pembelajaran, mereka kreatif dalam menciptakan obrolan ataupun menarik perhatian teman-temannya di kelas, dan juga seringkali memenangkan permainan di jam istirahat mereka. Tetapi di sisi lain, mereka tidak selalu mencapai nilai tertinggi dalam pembelajaran matematika. Meskipun secara keseluruhan nilai rata-ratanya meningkat tetapi belum sampai $80 \%$ dari jumlah siswa yang mencapai nilai lebih dari atau sama dengan KKM. Perubahan perilaku siswa yang terpantau pada siklus ini yaitu siswa mengenali berbagai strategi, berani mengganti strateginya, melakukan estimasi, serta mengemukakan efek dari suatu operasi bilangan.

Siklus III disusun berdasarkan evaluasi yang dilakukan pada siklus II akan tetapi kali ini kenyaatan di lapangan meleset dari perkiraan. Siklus III diawali dengan permainan yang mengembangkan kemampuan siswa untuk menggunakan hubungan diantara operasi aritmatika dan membuat sistem acuan/patokan yang diakhiri dengan aplikasi dari hubungan operasi aritmatika tersebut. Kenyataan yang terjadi setelah tindakan ke-2 dilaksanakan adalah siswa mengalami kesulitan dalam mengerjakan evaluasi yang diberikan oleh guru akibat energinya terkuras oleh permainan pengurangan bilangan bulat dua digit angka. Rupanya pemilihan aktivitas permainan berpengaruh terhadap evaluasi pembelajaran siswa. Hasil dari evaluasi pembelajaran pada siklus III didapatkan nilai rata-rata kelas 59 dan hanya 16 siswa yang tuntas dari 29 siswa di kelas pada hari itu meskipun pada siklus ini guru juga membimbing siswa untuk menuliskan alasannya menjawab pertanyaan pada kertas mereka. Walaupun hasil evaluasi menunjukkan nilai rata-rata kelas yang menurun tetapi ada peningkatan hasil pada soal uraian yang berisi tentang pemilihan metode yang efisien. Peningkatannya cukup signifikan yaitu dari siklus II sebesar 7\% menjadi 46\% pada siklus III ini. Hal ini mengindasikan bahwa permainan yang diberikan pada siklus ini memberikan dampak positif utamanya dalam hal memilih metode yang efisien. Selain itu pada siklus ini siswa bisa menghitung kartu-kartu poker yang telah disusun dalam 9 amplop dengan rata-rata waktu 10 menit. Siswa pada siklus ini menunjukkan adanya perubahan dalam hal menggunakan angka acuan dan kemampuan menyimpulkan mengenai 
adanya hubungan antara konteks masalah dan perhitungan yang sesuai. Permainan menghitung cepat dikerjakan dengan mengadopsi strategi permainan zip menunjukkan bahwa siswa mulai mengenal perlunya menggunakan angka acuan dalam perhitungan dan siswa mulai dapat menyimpulkan mengenai adanya hubungan antara konteks masalah dan cara perhitungan yang sesuai.

Berdasarkan evaluasi dari siklus III yang menunjukkan bahwa kemampuan number sense siswa belum berkembang secara optimal maka dibuatlah perencanaan pelaksanaan siklus IV. Siklus IV dirancang untuk mengembangkan kemampuan siswa dalam membuat sistem acuan/patokan dan menggunakan hubungan diantara operasi aritmatika. Permainan tebak angka dan 21 ternyata mampu mengatasi hal ini, yang terlihat dari rata-rata kelas yang meningkat menjadi 68 dan 26 siswa memperoleh nilai $\geq 60$. Dari 3 siswa yang nilainya kurang dari KKM atau $<60,2$ diantaranya mendapatkan nilai 50 dan 55 , sedangkan 1 siswa mendapatkan nilai hanya 20 poin saja. Artinya hampir seluruh siswa dari 29 siswa telah meningkat kemampuan number sensenya. Hal lain yang mengindikasikan peningkatan kemampuan number sense siswa adalah pada tahap evaluasi guru tidak lagi membimbing siswa untuk menuliskan uraian cara pengerjaan soal. Guru dalam hal ini hanya memantau jawaban siswa dan mengingatkan mereka untuk menuliskan alasannya saja. Perubahan perilaku siswa yang mengindikasikan perkembangan number sense pada siklus ini terlihat dari siswa dapat memilih metode yang efisien serta meninjau ulang data dan hasil perhitungan.

Metode learning by playing memberikan keleluasaan bagi siswa untuk mengeksplorasi lingkungan permainan dengan cara yang kreatif. Siswa bebas mencoba berbagai macam cara guna memenangkan permainan, bahkan kadangkala cara yang mereka gunakan tidak pernah ada di buku manapun tetapi menjadi cara yang cukup jitu untuk memecahkan masalah. Caracara kreatif seperti menggabungkan beberapa kartu yang tidak senilai dan sewarna merupakan cara yang tidak ada di buku pelajaran matematika mereka, namun dapat ditemukan oleh siswa. Cara kreatif dalam memecahkan masalah inilah yang menyebabkan kemampuan number sense siswa berkembang.

Metode learning by playing menciptakan suasana senang sehingga 
Kemampuan Number Sense

Melalui Metode Learning By Playing

Tunjung Susilowati

mendorong terjadinya pembelajaran. Dialog yang terjadi antara guru Siswa dengan hati yang gembira dan siswa terfasilitasi oleh penggunaan mengikuti pembelajaran sehingga tidak lagi menganggap matematika sebagai pembelajaran yang menakutkan. Terciptanya suasana menyenangkan pada saat yang sama tidak membebani siswa untuk memikirkan strategi pemecahan masalah yang berat sekalipun. Tentu saja hal ini mendorong siswa untuk menciptakan cara kreatif apalagi dengan adanya pengelompokkan non formal sehingga siswa bisa saling belajar strategi satu sama lain.

Metode learning by playing menciptakan hubungan yang kaya antara kuantitas nyata dalam ruang dan waktu, penghitungan angka dalam bahasa lisan, dan simbol formal. Siswa yang bermain menggunakan media seperti topi merah putih, kartu poker, dan kartu bergambar lingkaran biru dan merah sebagai perwakilan kuantitas nyata dalam ruang dan waktu beralih ke dalam penghitungan bahasa lisan kemudian membuat simbol formal di kepala pada akhirnya membantu siswa mencipta otomatisasi di kepalanya saat memecahkan suatu masalah. Otomatisasi dalam menghitung mengindikasikan perkembangan kemampuan number sense siswa. 
2. Metode learning by playing membuat siswa belajar dengan senang hati tanpa merasa terpaksa atau dipaksa untuk mempelajarinya, hal ini disebabkan karena adanya motivasi intrinsik siswa untuk berlajar.

3. Metode learning by playing memberikan anak-anak kepercayaan diri untuk mencoba strategi, mengambil resiko, berusaha mandiri dan pada akhirnya mengembangkan percaya diri dalam matematika.

4. Alat peraga yang digunakan membantu siswa untuk mengembangkan pemahaman simbolik.

5. Pelaksanaan pembelajaran dalam kelompok dapat membuat siswa tanpa ragu mengeksplorasi cara guna memecahan masalah yang dihadapi dan pada akhirnya mendapatkan informasi baru.

6. Metode learning by playing mendorong siswa untuk merencanakan, mencoba, dan meninjau ulang strategi pemecahan masalah yang mereka buat.

7. Metode learning by playing memberi waktu bagi siswa mengulang, mempraktikkan, dan menguasai materi.
8. Permainan yang dilakukan dalam pelaksanaan metode learning by playing memberikan siswa kontrol dan tanggung jawab.

9. Kemampuan memprediksi didapatkan siswa melalui pembelajaran dengan metode learning by playing.

10. Metode learning by playing memberikan kesempatan bagi siswa untuk mengkomunikasikan perasaan dan pemahaman mereka terhadap pembelajaran.

11. Metode learning by playing dapat meningkatkan kemampuan number sense dalam penjumlahan dan pengurangan bilangan bulat pada siswa kelas V SD Kristen Calvin Jakarta pusat.

\section{DAFTAR RUJUKAN}

Bresser, Rusty dan Caren Holtzman. ,1999. Developing Number Sense Grades 3-6. Sausalito: Math Solutions Publications

Cross, Christopher T., Taniesha A. Woods, dan Heidi Schweingruber. 2009. Mathematic Learning in Early Childhood, Paths Toward Excellence and Equity. Washington: The National Academy of Sciences

Dehaene, Stanislas. 2011. The Number Sense How The Mind Creates Mathematics. New York: Oxford University Press 
Kemampuan Number Sense

Melalui Metode Learning By Playing

Tunjung Susilowati

Griffin, Sharon, 2004. "Teaching Number Sense," Educational Leadership, Volume 61, Nomor 5, Februari

McIntosh, Alistair, Barbara J.Reys, dan Robert E.Reys. 2005 Subject Learning in the Primary Curriculum: Issues in English, Science, and Mathematics. Taylor $\&$ Francis e-Library

National Council of Teachers of Mathematics. Principles and Standards for School Mathematics. Reston : The National Council of Teachers of Mathematics, Inc., 2000.

Richardson, Kathy. 2004. Engaging Young Children in Mathematics: Standards for Early Childhood Mathematics Education. New Jersey: Lawrence Erlbaum Associates, Inc 